\title{
Doublet vs Single-Agent Maintenance Therapy in the Treatment of Non-Small-Cell Lung Cancer: A Meta-Analysis
}

This article was published in the following Dove Press journal: Drug Design, Development and Therapy

Jing $Q i^{1}$

Xiuzhi Guo'

Aihua $\mathrm{Li}^{2}$

'Department of Respiration Medicine, Tai'an Central Hospital, Tai'an,

${ }^{2}$ Department of Respiration Medicine, Yankuang Group General Hospital, Jining, China
Correspondence: Aihua $\mathrm{Li}$

Department of Respiration Medicine, Yankuang Group General Hospital, 560 Kuangjian East Road, Jining, Shandong 273500, China

Tel +865375367018

Fax +865375367017

Email lahykjtzyy@sohu.com
Background: Several published meta-analyses have confirmed that single-agent maintenance therapy in advanced non-small-cell lung cancer (NSCLC) can prolong time to disease progression and potentially increase overall survival (OS) in comparison to placebo. However, whether doublet maintenance therapy can improve the survival of advanced NSCLC remains undetermined.

Methods: We searched several databases for relevant trials. Prospective randomized controlled trials comparing doublet vs single-agent maintenance therapy in NSCLC patients were included for analysis. Outcomes of interest were OS, progression-free survival (PFS), and incidence of grade $3 / 4$ toxicities.

Results: A total of 1,950 advanced-NSCLC patients from six trials were included for analysis. Our results showed that doublet maintenance therapy in NSCLC patients significantly improved PFS (HR 0.74, 95\% CI $0.59-0.93 ; P=0.010$ ), but not for OS (HR 0.95, 95\% CI $0.85-1.07 ; P=0.40)$ in comparison with single-agent maintenance therapy. Subgroup analysis by maintenance regimen showed that pemetrexed plus bevacizumab maintenance therapy significantly improved PFS, but not OS. In addition, there was no significant risk difference between doublet and single-agent maintenance therapy in terms of grade 3/4 hematologic and nonhematologic toxicities.

Conclusion: Our study suggests that doublet maintenance therapy in advanced-NSCLC patients demonstrates PFS benefits, but not OS benefits, in comparison with single-agent maintenance therapy. Future trials are suggested to assess the long-term clinical benefit of doublet maintenance treatment in NSCLC patients and its impact on health-related quality of life.

Keywords: targeted agents, maintenance therapy, doublet, single agent, meta-analysis

\section{Introduction}

Lung cancer remains one of the most common malignancies in the world and is the leading cause of cancer-related deaths worldwide, accounting for 1.59 million deaths yearly. ${ }^{1}$ Non-small-cell lung cancer (NSCLC) accounts for $80 \%-85 \%$ of lung cancer cases, which can be divided further into several subgroups, eg, adenocarcinoma, squamous-cell carcinoma, and large-cell carcinoma. Generally, NSCLC is often diagnosed at advanced stages, when treatment options are limited. Until now, platinum-based doublet chemotherapy remains the standard of care for advanced NSCLC, with good performance status, especially in those with tumors that are negative for sensitizing EGFR mutations, ROS1, and ALK. ${ }^{2}$ However, most 
patients will experience disease progression during or after first-line chemotherapy, demonstrating the need for new effective agents or treatment strategy. ${ }^{3}$

Maintenance therapy may prolong time to disease progression and potentially increase overall survival (OS). As a result, maintenance therapy with different drugs is one strategy that has been evaluated extensively in recent years. ${ }^{4-6}$ Indeed, several published meta-analyses have confirmed that single-agent maintenance therapy in advanced NSCLC can prolong time to disease progression and potentially increase OS in comparison to placebo. ${ }^{7-9}$ To date, maintenance therapy with pemetrexed or erlotinib has demonstrated improved OS, resulting in US Food and Drug Administration approval for this indication. ${ }^{6}$ Recently, doublet maintenance therapy has been investigated in multiple prospective clinical trials, but the results are controversial. As a result, we conducted the present meta-analysis of all available randomized controlled trials to determine the overall efficacy and toxicity of doublet maintenance therapy in advanced NSCLC patients.

\section{Methods}

\section{Data Sources}

Several databases, including PubMed, Web of Science, and the Cochrane Library, were searched for relevant trials. The search keywords were maintenance therapy, erlotinib, gefitinib, pemetrexed, gemcitabine, targeted agents, non-small-cell lung cancer, and clinical trials. Additionally, relevant articles in the reference lists of recent meta-analyses that investigated maintenance therapy in NSCLC patients were also searched. In order to avoid duplication, only the most complete and recent trials were considered for analysis. All results were entered into Endnote X8 reference software (Clarivate Analytics, Philadelphia, PA, USA) for duplication exclusion and further reference management.

\section{Study Selection}

Clinical trials that met the criteria of prospective randomized controlled phase II or III trials involving NSCLC patients, randomized clinical trials comparing doublet vs single-agent maintenance therapy, and available survival and toxicity data on maintenance therapy in NSCLC patients were included. If multiple publications of the same trial were retrieved or there was a case mix between publications, only the most recent publication (and the most informative) was included.

\section{Data Extraction}

Two independent investigators conducted data abstraction, and any discrepancy between the reviewers was resolved by consensus. Information extracted for each study was first author's name, year of publication, trial phase, number of enrolled subjects, treatment arms, maintenance arms, median age, median progression-free survival (PFS), and median OS.

\section{Outcome Measures}

A formal meta-analysis was conducted using Comprehensive Meta Analysis software version 2.0. Outcome data were pooled and reported as HRs. The primary outcome of interest was OS and secondary outcomes PFS or severe toxicity in NSCLC patients receiving maintenance therapy. Toxicities were defined by the National Cancer Institute's Common Terminology Criteria for Adverse Events during a clinical trial as a result of exposure to an experimental drug, which has been used widely in clinical cancer trials. ${ }^{10}$ Between-study heterogeneity was estimated using the $\chi^{2}$-based $Q$ statistic. ${ }^{11}$ Heterogeneity was considered statistically significant when $P_{\text {heterogeneity }}<0.1$. The presence of publication bias was evaluated using Begg and Egger tests. ${ }^{12,13}$ $P<0.05$ was considered significant. Study quality was assessed using the Jadad scale based on the reporting of the studies' methods and results. ${ }^{14}$

\section{Results}

\section{Search Results}

We performed the systematic review and meta-analysis in accordance with the PRISMA (preferred reporting items for systematic reviews and meta-analyses) statement. ${ }^{15}$ Our initial search yielded 450 potentially relevant reports. After exclusion of review articles, Phase I studies, case reports, meta-analyses, and observation studies, seven prospective randomized controlled clinical trials were included. After review of included trials, two were undated analyses of previously published trials ${ }^{16,17}$ and only the most recent publication (and the most informative) was included. ${ }^{17}$ Finally, a total of 1,950 advanced NSCLC patients from six trials were included for analysis (Figure 1). ${ }^{17-22}$ Table 1 lists the baseline characteristics of patients and studies. The quality of each study was roughly assessed according to the Jadad scale, and two of the six randomized controlled trials were double-blind placebo-controlled, and thus had a Jadad score of 5. The 


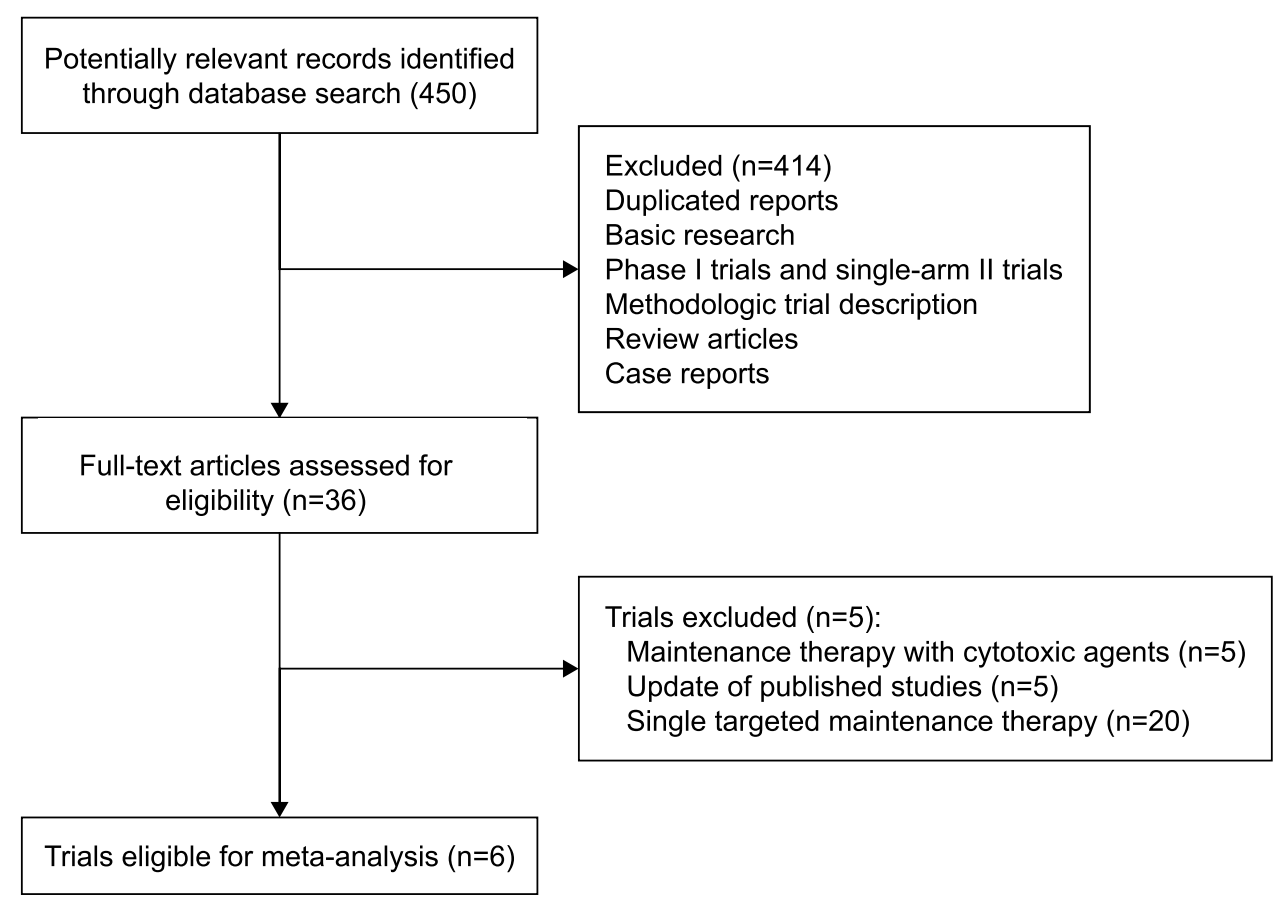

Figure I Studies eligible for inclusion in the meta-analysis.

other three trials were open-label controlled, and thus had a Jadad score of 3 .

\section{Progression-Free Survival}

All six trials reported PFS data for doublet vs single-agent maintenance therapy in NSCLC patients. The pooled HR for PFS demonstrated that doublet maintenance therapy in NSCLC patients significantly improved PFS (HR 0.74, 95\% CI $0.59-0.93 ; P=0.010$; Figure 2 ) in comparison with single-agent maintenance therapy. There was significant heterogeneity among trials $\left(I^{2}=67.6 \%, P=0.009\right)$, and the pooled HR for PFS was calculated using a randomeffect model. Subgroup analysis according to maintenance regimen showed that pemetrexed plus bevacizumab maintenance therapy (HR $0.67,95 \%$ CI $0.46-0.98 ; P=0.0037$ ) in NSCLC patients significantly improved PFS in comparison with single-agent maintenance therapy, but not for other doublet maintenance therapy (HR 0.79, 95\% CI $0.59-1.05 ; P=0.104)$.

\section{Overall Survival}

Six trials reported OS data of doublet vs single-agent maintenance therapy in NSCLC patients. The pooled HR for OS indicated that doublet maintenance therapy in NSCLC patients did not significantly improve OS (HR $0.95,95 \%$ CI $0.85-1.07 ; P=0.41$; Figure 3 ) in comparison with single-agent maintenance therapy. There was no significant heterogeneity between trials $\left(I^{2}=0, P=0.47\right)$, and the pooled HR for OS was calculated using a fixed-effect model. We then performed subgroup analysis according to maintenance regimen, and found that both pemetrexed plus bevacizumab (HR 0.97, 95\% CI 0.85-1.11; $P=0.67$ ) and other doublet maintenance-therapy agents (HR 0.91, 95\% CI 0.74-1.12; $P=0.37$ ) did not significantly improve OS in comparison with single-agent maintenance therapy.

\section{Toxicity}

Pooled analysis of reported grade 3 and 4 adverse events of interest was also performed. There was no significant risk difference between doublet and single-agent maintenance therapy in terms of grade 3/4 hematologic (anemia, neutropenia, and thrombocytopenia) and nonhematologic toxicity (diarrhea, nausea, and fatigue; Table 2).

\section{Publication Bias}

Begg's funnel plot and Egger's test were performed to assess publication bias in the literature. The shapes of the funnel plots did not reveal any obvious asymmetry ( $P=0.85$ for PFS and $P=0.45$ for OS). Egger's test was used to provide statistical evidence of funnel-plot symmetry. The results suggested no evidence of publication bias for PFS or OS ( $P=0.60, P=0.38$, respectively). 
Table I Baseline Characteristics of Trials Included

\begin{tabular}{|c|c|c|c|c|c|c|c|c|}
\hline & Population & $\begin{array}{l}\text { Induction } \\
\text { Therapy }\end{array}$ & $\begin{array}{l}\text { Maintenance } \\
\text { Therapy }\end{array}$ & $\begin{array}{l}\text { Maintenance } \\
\text { Patients, n }\end{array}$ & $\begin{array}{l}\text { Median } \\
\text { Age, } \\
\text { Years }\end{array}$ & $\begin{array}{l}\text { Median PFS, } \\
\text { (interquartile } \\
\text { range, IQR), } \\
\text { months }\end{array}$ & $\begin{array}{l}\text { Median OS, } \\
\text { (interquartile } \\
\text { range, IQR), } \\
\text { months }\end{array}$ & $\begin{array}{l}\text { Jadad } \\
\text { Score }\end{array}$ \\
\hline $\begin{array}{l}\text { Barlesi } \\
\text { et } \text { al }^{17}\end{array}$ & $\begin{array}{l}\text { CT-naïve, stage } \\
\text { IIIB-IV, } \\
\text { nonsquamous, } \\
\text { ECOG PS 0-2 }\end{array}$ & $\begin{array}{l}\text { Pemetrexed + } \\
\text { cisplatin }+ \\
\text { bevacizumab }\end{array}$ & $\begin{array}{l}\text { Bevacizumab + } \\
\text { pemetrexed }\end{array}$ & 128 & NR & $\begin{array}{l}7.4(0.48 \\
0.35-0.66)\end{array}$ & $\begin{array}{l}19.8(0.88 \\
0.63-\mid .2 I)\end{array}$ & 3 \\
\hline $\begin{array}{l}\text { Johnson } \\
\text { et } \mathrm{al}^{22}\end{array}$ & $\begin{array}{l}\text { CT-naïve, stage } \\
\text { IIIB-IV or } \\
\text { recurrent, } \\
\text { ECOG PS 0-I }\end{array}$ & $\begin{array}{l}\text { Chemotherapy } \\
+ \text { bevacizumab }\end{array}$ & $\begin{array}{l}\text { Bevacizumab } \\
\text { Bevacizumab + } \\
\text { erlotinib }\end{array}$ & $\begin{array}{l}125 \\
370\end{array}$ & $\begin{array}{l}N R \\
64\end{array}$ & $\begin{array}{l}3.7 \\
4.8(0.71, \\
0.58-0.86)\end{array}$ & $\begin{array}{l}15.9 \\
14.4(0.92 \\
0.70-1.21)\end{array}$ & 5 \\
\hline $\begin{array}{l}\text { Patel } \\
\text { et } \mathrm{al}^{21}\end{array}$ & $\begin{array}{l}\text { CT-naïv, } \\
\text { nonsquamous, } \\
\text { stage IIIB-IV } \\
\text { or recurrent, } \\
\text { ECOG PS 0-I }\end{array}$ & $\begin{array}{l}\text { Chemotherapy } \\
+ \text { bevacizumab }\end{array}$ & $\begin{array}{l}\text { Bevacizumab } \\
\text { placebo } \\
\text { Bevacizumab + } \\
\text { pemetrexed }\end{array}$ & $\begin{array}{l}373 \\
292\end{array}$ & $\begin{array}{l}64 \\
63.8\end{array}$ & $\begin{array}{l}3.7 \\
6(0.73, \\
0.7 I-0.96)\end{array}$ & $\begin{array}{l}13.3 \\
12.6(1, \\
0.86-1.16)\end{array}$ & 3 \\
\hline $\begin{array}{l}\text { Karayama } \\
\text { et } \mathrm{al}^{20}\end{array}$ & $\begin{array}{l}\text { CT-naïe, } \\
\text { nonsquamous, } \\
\text { stage IIIB-IV } \\
\text { or recurrent, } \\
\text { ECOG PS 0-I }\end{array}$ & $\begin{array}{l}\text { Pemetrexed + } \\
\text { carboplatin + } \\
\text { bevacizumab }\end{array}$ & $\begin{array}{l}\text { Bevacizumab } \\
\text { Bevacizumab + } \\
\text { pemetrexed }\end{array}$ & $\begin{array}{l}298 \\
45\end{array}$ & $\begin{array}{l}64.3 \\
66\end{array}$ & $\begin{array}{l}5.6 \\
\text { II.5 (0.73, } \\
0.44-I .19)\end{array}$ & $\begin{array}{l}13.4 \\
24.4,0.87,95 \% \\
\text { Cl } 0.49-1.54\end{array}$ & 3 \\
\hline $\begin{array}{l}\text { Ciuleanu } \\
\text { et } \text { al }^{19}\end{array}$ & $\begin{array}{l}\text { CT-naïve, stage } \\
\text { IV or } \\
\text { recurrent, } \\
\text { ECOG PS 0-I }\end{array}$ & $\begin{array}{l}\text { Platinum-based } \\
\text { CT }\end{array}$ & $\begin{array}{l}\text { Pemetrexed } \\
\text { Linsitinib + } \\
\text { erlotinib }\end{array}$ & $\begin{array}{l}35 \\
102\end{array}$ & $\begin{array}{l}65 \\
62\end{array}$ & $\begin{array}{l}7.3 \\
125,1.09 \\
(0.788-\mid .507)\end{array}$ & $\begin{array}{l}21.3 \\
381,1.20 \\
(0.777,1.853)\end{array}$ & 5 \\
\hline $\begin{array}{l}\text { Niho } \\
\text { et } \mathrm{al}^{18}\end{array}$ & $\begin{array}{l}\text { CT-naïve, stage } \\
\text { IIIB-IV or } \\
\text { recurrent, } \\
\text { ECOG PS 0-I }\end{array}$ & $\begin{array}{l}\text { Platinum-based } \\
\text { CT }\end{array}$ & $\begin{array}{l}\text { Placebo }+ \\
\text { erlotinib } \\
\text { SI }+ \\
\text { bevacizumab } \\
\text { Bevacizumab }\end{array}$ & $\begin{array}{l}103 \\
39 \\
40\end{array}$ & $\begin{array}{l}60 \\
61 \\
65\end{array}$ & $\begin{array}{l}129 \\
4.6(0.64, \\
0.45-0.91) \\
2.6\end{array}$ & $\begin{array}{l}421 \\
19.9(0.65, \\
0.4 \mid-1.02) \\
11.0\end{array}$ & 3 \\
\hline
\end{tabular}

Abbreviations: PFS, progression-free survival; OS, overall survival; CT, chemotherapy; ECOG, Eastern Cooperative Oncology Group; PS, performance status; NR, not reported.

\section{Discussion}

First-line platinum-based chemotherapy of four or six cycles has reached a plateau of effectiveness for the treatment of advanced NSCLC. Unfortunately, the prognosis of these patients is poor, with 5-year survival, $5 \%{ }^{23}$ Maintenance therapy has emerged as a novel treatment strategy for advanced NSCLC patients. Indeed, multiple clinical trials have demonstrated that single-agent erlotinib or pemetrexed maintenance therapy in advanced NSCLC provides superior PFS and OS in comparison with placebo, which led to the approval of erlotinib and pemetrexed as maintenance therapy in these patients. ${ }^{24-30}$ However, to the best of our knowledge, whether doublet therapy would improve efficacy in comparison with single-agent maintenance therapy remains undetermined.

In the preset meta-analysis, 1,950 advanced NSCLC patients from six trials were included. Our results showed that doublet maintenance therapy in NSCLC patients significantly improved PFS (HR $0.73,95 \%$ CI $0.60-0.89$; $P=0.002$ ), but not OS (HR 0.95 , 95\% CI 0.85-1.07; $P=0.40$ ) in comparison with single-agent maintenance therapy. We then performed subgroup analysis according to maintenance regimen, and found that pemetrexed plus bevacizumab maintenance therapy significantly improved PFS, but not OS. In addition, the toxicity of doublet maintenance therapy was minimal and well tolerated. There was no significant risk difference between doublet 


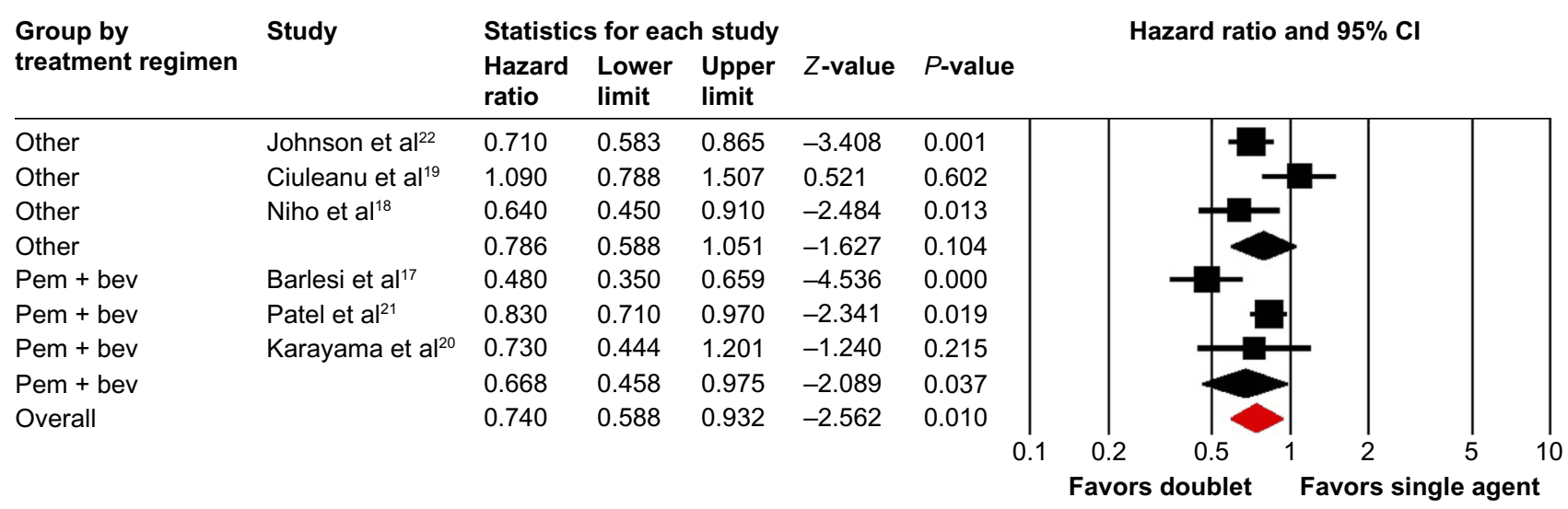

Figure 2 Random-effect model of hazard ratio $(95 \% \mathrm{Cl})$ for PFS in NSCLC treated with doublet vs single-agent maintenance therapy. Abbreviations: PFS, progression-free survival; NSCLC, non-small-cell lung cancer; Pem, pemetrexed; Bev, bevacizumab.

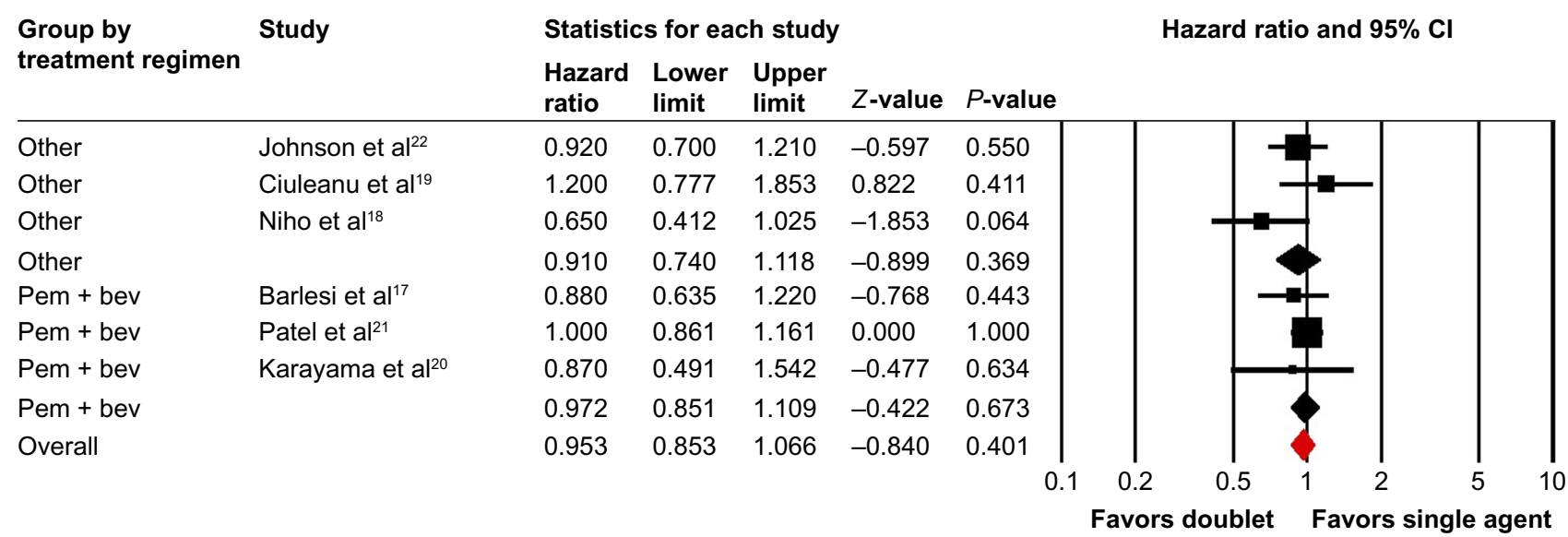

Figure 3 Fixed-effect model of $\mathrm{HR}(95 \% \mathrm{Cl})$ of OS in NSCLC treated with doublet vs single-agent maintenance therapy. Abbreviations: OS, overall survival; NSCLC, non-small-cell lung cancer; Pem, pemetrexed; Bev, bevacizumab.

and single-agent maintenance therapy in terms of grade $3 / 4$ hematologic and nonhematologic toxicity.

Given only modest improvement in PFS or OS obtained from maintenance therapy, quality of life (QOL) is another issue of concern for patients and physicians. However, none of the trials reported QOL results for doublet vs singleagent maintenance therapy in NSCLC patients. Several single-agent maintenance trials incorporated QOL analysis into theirdesign, and found that QOL was not significantly worse with maintenance therapy and may have delayed time to pain or other disease-related symptoms. ${ }^{29,31}$ As a result, future studies are recommended to investigate the impact of doublet maintenance therapy on health-related QOL.

Table 2 Outcome of Grade 3 or 4 Toxicity Comparing Doublet vs Single-Agent Maintenance Therapy

\begin{tabular}{|c|c|c|c|c|c|c|c|}
\hline \multirow[t]{2}{*}{ Toxic events } & \multirow[t]{2}{*}{ Trials } & \multirow[t]{2}{*}{ Doublet } & \multirow[t]{2}{*}{ Single Agent } & \multicolumn{2}{|c|}{ Heterogeneity } & \multirow[t]{2}{*}{ RR $(95 \% \mathrm{Cl})$} & \multirow[t]{2}{*}{$P$-value } \\
\hline & & & & $P$-value & $I^{2}$ & & \\
\hline Grade 3-4 anemia & 3 & $8 / 212$ & $2 / 200$ & 0.26 & 26.0 & $2.24(0.47-10.6)$ & 0.31 \\
\hline Grade $3-4$ neutropenia & 3 & $14 / 212$ & $3 / 200$ & 0.11 & 54.5 & $3.44(0.45-26.2)$ & 0.23 \\
\hline Grade 3-4 thrombocytopenia & 3 & $1 / 212$ & $0 / 200$ & 0.98 & 0 & $2.35(0.10-55.9)$ & 0.60 \\
\hline Grade 3-4 diarrhea & 4 & $43 / 511$ & $14 / 5 \mid 6$ & 0.025 & 73.0 & $2.23(0.52-9.56)$ & 0.28 \\
\hline Grade 3-4 nausea & 4 & $23 / 3 \mid 4$ & $12 / 303$ & 0.74 & 0 & $1.71(0.89-3.31)$ & 0.11 \\
\hline Grade 3-4 fatigue & 4 & $7 / 314$ & $7 / 303$ & 0.72 & 0 & $0.95(0.33-2.72)$ & 0.93 \\
\hline
\end{tabular}


There are several limitations to this analysis. First, we included only published trials, and a meta-analysis of individual-level data might define treatment benefits in specific subgroups more clearly. Second, different doublet maintenance regimens were included for analysis, which might have increased the heterogeneity among the trials. In addition, we could not answer which regimen is the best choice. Third, the optimal timing and duration of maintenance therapies using different targeted agents still need to be defined in further studies. Finally, publication bias is an important issue in meta-analyses, because trials with positive results are more likely to be published. Our paper did not detect publication bias for PFS or OS.

\section{Conclusion}

Our study suggests that doublet maintenance therapy in advanced NSCLC patients demonstrates PFS benefits, but not OS benefits, in comparison with single-agent maintenance therapy. In addition, doublet maintenance therapy did not significantly increase the risk of severe toxicity when compared to single-agent maintenance therapy. Future trials are suggested to assess the long-term clinical benefit of doublet maintenance treatment in NSCLC patients and its impact onhealth-related QOL.

\section{Disclosure}

The authors report no conflicts of interest in this work.

\section{References}

1. Siegel R, Ma J, Zou Z, Jemal A. Cancer statistics, 2014. CA Cancer J Clin. 2014;64(1):9-29.

2. Shepherd FA, Bunn PA, Paz-Ares L. Lung cancer in 2013: state of the art therapy for metastatic disease. Am Soc Clin Oncol Educ Book. 2013:339-346.

3. Blakely C, Jahan T. Emerging antiangiogenic therapies for non-smallcell lung cancer. Expert Rev Anticancer Ther. 2011;11(10):1607-1618.

4. Minami S, Kijima T. Pemetrexed in maintenance treatment of advanced non-squamous non-small-cell lung cancer. Lung Cancer. 2015;6:13-25.

5. Lee JE, Chung CU. Update on the evidence regarding maintenance therapy. Tuberc Respir Dis. 2014;76(1):1-7.

6. Gerber DE, Schiller JH. Maintenance chemotherapy for advanced non-small-cell lung cancer: new life for an old idea. J Clin Oncol. 2013;31(8):1009-1020.

7. Wang Q, Huang H, Zeng X, Ma Y, Zhao X, Huang M. Single-agent maintenance therapy for advanced non-small cell lung cancer (NSCLC): a systematic review and Bayesian network meta-analysis of 26 randomized controlled trials. Peer J. 2016;4:e2550.

8. Hu X, Pu K, Feng X, et al. Role of Gemcitabine and Pemetrexed as Maintenance Therapy in Advanced NSCLC: A Systematic Review and Meta-Analysis of Randomized Controlled Trials. PLoS One. 2016;11 (3): 0149247.
9. Lu S, Yu Y, Chen Z, Ye X, Li Z, Niu X. Maintenance Therapy Improves Survival Outcomes in Patients with Advanced Non-small Cell Lung Cancer: A Meta-analysis of 14 Studies. Lung. 2015;193 (5):805-814.

10. NCI, Cancer Therapy Evaluation Program. CTC v 2.0 and common terminology criteria for adverse events criteria V3.0 (CTCAE); 2006. Available from: http://ctep.cancer.gov/reporting/

11. Zintzaras E, Ioannidis JP. Heterogeneity testing in meta-analysis of genome searches. Genet Epidemiol. 2005;28(2):123-137.

12. Yusuf S, Peto R, Lewis J, Collins R, Sleight P. Beta blockade during and after myocardial infarction: an overview of the randomized trials. Prog Cardiovasc Dis. 1985;27(5):335-371.

13. Begg CB, Mazumdar M. Operating characteristics of a rank correlation test for publication bias. Biometrics. 1994;50(4):10881101.

14. Moher D, Pham B, Jones A, et al. Does quality of reports of randomised trials affect estimates of intervention efficacy reported in meta-analyses? Lancet. 1998;352(9128):609-613.

15. Moher D, Liberati A, Tetzlaff J, Altman DG; PRISMA Group. Preferred reporting items for systematic reviews and meta-analyses: the PRISMA statement. PLoS Med. 2009;6(7):e1000097.

16. Barlesi F, Scherpereel A, Gorbunova V, et al. Maintenance bevacizumab-pemetrexed after first-line cisplatin-pemetrexedbevacizumab for advanced nonsquamous nonsmall-cell lung cancer: updated survival analysis of the AVAPERL (MO22089) randomized phase III trial. Ann Oncol. 2014;25(5):1044-1052.

17. Barlesi F, Scherpereel A, Rittmeyer A, et al. Randomized phase III trial of maintenance bevacizumab with or without pemetrexed after first-line induction with bevacizumab, cisplatin, and pemetrexed in advanced nonsquamous non-small-cell lung cancer: AVAPERL (MO22089). J Clin Oncol. 2013;31(24):3004-3011.

18. Niho S, Ohe Y, Ohmatsu H, et al. Switch maintenance chemotherapy using S-1 with or without bevacizumab in patients with advanced non-small cell lung cancer: a phase II study. Lung Cancer. 2017;108:66-71.

19. Ciuleanu TE, Ahmed S, Kim JH, et al. Randomised Phase 2 study of maintenance linsitinib (OSI-906) in combination with erlotinib compared with placebo plus erlotinib after platinum-based chemotherapy in patients with advanced non-small cell lung cancer. $\mathrm{Br} J$ Cancer. 2017;117(6):757-766.

20. Karayama M, Inui N, Fujisawa T, et al. Maintenance therapy with pemetrexed and bevacizumab versus pemetrexed monotherapy after induction therapy with carboplatin, pemetrexed, and bevacizumab in patients with advanced non-squamous non small cell lung cancer. Eur J Cancer. 2016;58:30-37.

21. Patel JD, Socinski MA, Garon EB, et al. PointBreak: a randomized phase III study of pemetrexed plus carboplatin and bevacizumab followed by maintenance pemetrexed and bevacizumab versus paclitaxel plus carboplatin and bevacizumab followed by maintenance bevacizumab in patients with stage IIIB or IV nonsquamous non-small-cell lung cancer. $J$ Clin Oncol. 2013;31(34):4349-4357.

22. Johnson BE, Kabbinavar F, Fehrenbacher L, et al. ATLAS: randomized, double-blind, placebo-controlled, phase IIIB trial comparing bevacizumab therapy with or without erlotinib, after completion of chemotherapy, with bevacizumab for first-line treatment of advanced non-small-cell lung cancer. J Clin Oncol. 2013;31(31):3926-3934.

23. Sullivan I, Planchard D. Treatment modalities for advanced ALK-rearranged non-small-cell lung cancer. Future Oncol. 2016;12 (7):945-961.

24. Genestreti G, di Battista M, Cavallo G, Bartolotti M, Brandes AA. Maintenance therapy in non-small cell lung cancer. Expert Rev Anticancer Ther. 2015;15(7):839-846.

25. Gentzler RD, Patel JD. Maintenance treatment after induction therapy in non-small cell lung cancer: latest evidence and clinical implications. Ther Adv Med Oncol. 2014;6(1):4-15. 
26. Zhang L, Ma S, Song X, et al. Gefitinib versus placebo as maintenance therapy in patients with locally advanced or metastatic non-small-cell lung cancer (INFORM; C-TONG 0804): a multicentre, double-blind randomised phase 3 trial. Lancet Oncol. 2012;13(5):466-475.

27. Pérol M, Chouaid C, Pérol D, et al. Randomized, phase III study of gemcitabine or erlotinib maintenance therapy versus observation, with predefined second-line treatment, after cisplatin-gemcitabine induction chemotherapy in advanced non-small-cell lung cancer. $J$ Clin Oncol. 2012;30(28):3516-3524.

28. Paz-Ares L, de Marinis F, Dediu M, et al. Maintenance therapy with pemetrexed plus best supportive care versus placebo plus best supportive care after induction therapy with pemetrexed plus cisplatin for advanced non-squamous non-small-cell lung cancer (PARAMOUNT): a double-blind, phase 3, randomised controlled trial. Lancet Oncol. 2012;13(3):247-255.
29. Cappuzzo F, Ciuleanu T, Stelmakh L, et al. Erlotinib as maintenance treatment in advanced non-small-cell lung cancer: a multicentre, randomised, placebo-controlled phase 3 study. Lancet Oncol. 2010;11(6):521-529.

30. Ciuleanu T, Brodowicz T, Zielinski C, et al. Maintenance pemetrexed plus best supportive care versus placebo plus best supportive care for non-small-cell lung cancer: a randomised, double-blind, phase 3 study. Lancet. 2009;374(9699):1432-1440.

31. Paz-Ares LG, de Marinis F, Dediu M, et al. PARAMOUNT: Final overall survival results of the phase III study of maintenance pemetrexed versus placebo immediately after induction treatment with pemetrexed plus cisplatin for advanced nonsquamous non-small-cell lung cancer. J Clin Oncol. 2013;31(23):2895-2902.

\section{Publish your work in this journal}

Drug Design, Development and Therapy is an international, peerreviewed open-access journal that spans the spectrum of drug design and development through to clinical applications. Clinical outcomes, patient safety, and programs for the development and effective, safe, and sustained use of medicines are a feature of the journal, which has also been accepted for indexing on PubMed Central. The manuscript management system is completely online and includes a very quick and fair peer-review system, which is all easy to use. Visit http://www. dovepress.com/testimonials.php to read real quotes from published authors. 